\title{
Profile of sexual offences: A 4 year retrospective study at tertiary care hospital of Western Maharashtra
}

\author{
Santosh Baburao Bhoi ${ }^{1}$, Kunal Bhimrao Shirsat ${ }^{2}$, Satin Kalidas Meshram ${ }^{3, *}$, Sushim Amrutrao Waghmare ${ }^{4}$, \\ Rizwan Allaudin Kamle ${ }^{5}$
}

${ }^{1,4}$ Associate Professor, ${ }^{2,5}$ Assistant Professor, ${ }^{3}$ Professor \& HOD, Dept. of Forensic Medicine, Dr. VM Govt. Medical College \& Shree CSMG Hospital, Solapur, Maharashtra

*Corresponding Author:

Email: drsatinfmt@yahoo.co.in

\begin{abstract}
Introduction: Sexual violence affects millions of women worldwide cutting across cultural and religious barriers. Although under reported, it is a frequent and significant public health issue in countries of both the developed and developing world.

Aims: This retrospective study was carried out to know the different aspects of sexual assault.

Materials and Method: This study was carried out in department of Forensic Medicine \& Toxicology, Dr Vaishampayan Memoral Government Medical College Solapur, Maharashtra from January 2013 to December 2016. This study is based on the medico-legal examination record of sexual assault victim.

Results: An increase in number of cases of sexual assault per year is observed. Age wise distribution showed that $59.60 \%$ cases were in age group 11-20 years consisting of major affected group. The $77.83 \%$ victims were unmarried. The victims from rural area were $41.16 \%$ and from urban area were $58.84 \%$. About $62.26 \%$ victims were student. In this study most of the assailants were known to the victim, only16.62 \% were strangers to victim. Most of the incidences $(38.52 \%)$ took place in assailant's house. In $19.79 \%$ cases there was evidence of external injury.

Conclusion Comprehensive reporting on all forms of sexual violence is necessary. Social awareness, sensitization and protection programs should be a high priority.
\end{abstract}

Keywords: Rape, Victim, Sexual offences, Solapur.

\section{Introduction}

The crime of rape is as old as mankind yet it has remained the most obnoxious and gravest of all human right violation. ${ }^{(1)}$ It has also been recognized as a gendered crime, constituting a violation of the right and freedom of women and fueling gender inequality. ${ }^{(2)}$ Its definition varies slightly across countries, culture and religion. According to world health organization, rape is a form of sexual violence, defined as physically forced or otherwise coerced penetration of the vulva or anus. $^{(3)}$

In India along with other considerations of circumstances mentioned in Criminal Procedure Code Section 375 the slightest penetration of the penis within the vulva, such as the minimal passage of glans between the labia with or without emission of semen or rupture of hymen constitutes a rape. ${ }^{(4)}$ In April 2013, the Indian Parliament introduced amendments to the Indian Penal Code (IPC) making various changes to the antirape laws in India. ${ }^{(5)}$ The definition is broadly defined in some aspect, with acts like penetration by penis, or any object or any part of body to any extent, into the vagina, mouth, urethra or anus of a woman or making her to do so with another person or applying of mouth to sexual organs without the consent or will of the woman constitutes the offence of rape. ${ }^{(6)}$

Sexual violence affects millions of women worldwide cutting across cultural and religious barriers. ${ }^{(7)}$ Although under reported, it is a frequent and significant public health issue in countries of both the developed and developing world. It is estimated that, worldwide, one in five women will become victim of rape or attempted rape in her lifetime. ${ }^{(8)}$ The under reporting of cases of sexual assault is mainly due to social stigma, prejudice with regard to the chances of marriage, being considered promiscuous and responsible for incident, attendant humiliation and shame, embarrassment caused by appearance and cross examination in court, publicity in press, risk of losing the love and respect of society, friends and that of her husband, if married. ${ }^{(9)}$

Present study has been carried out to identify the high risk population at earliest so that stringent legislative measures should be taken properly to safeguard the interest of the victims and society at large. This needs to go hand-in-hand with strengthening the criminal justice system's response to rape, both to provide victims with justice and to detain men likely to commit further rapes if left unchecked. Hence various factors associated with sexual offences against women is tried to be found through this study so as to develop some strategies to countercheck its occurrence.

\section{Materials and Method}

This 4 year retrospective study was carried out in the Department of Forensic Medicine and Toxicology, Dr Vaishampayan. Memoral Government Medical College Solapur, Maharashtra from January 2013 to December 2016 
This study is based on the record of sexual assault victims who had been brought for medico-legal examination in the department. The detailed pertaining to age, resident area of victim, marital status, place of incident, relationship with assailant, finding of physical examination were noted. The data was entered on predesigned data sheet, tabulated and then statistically analyzed.

Inclusion criterion: All the sexual offences victims brought to the department during the study period.

Ethical committee clearance: As the data was retrospectively collected and as no revelations of identity ethical committee clearance not required. However permission of head of the department is taken to collect the data.

\section{Conflict of interest and sources of funding: None}

\section{Results}

A total 379 cases were observed during the study period. Year wise distribution of cases showed that there was increase in number of incidence per year. In 2013 there were 39 cases $(10.29 \%)$, in 2014 there were 96 cases $(25.32 \%)$, and in 2016 cases were 144 (37.99\%).(Table 1)

Age wise distribution revealed that there were 226 cases $(59.60 \%)$ in age group 11-20 years. while in age group of 21-30 years cases were $87(22.95 \%)$ in age group 31-40 years there were 32 cases $(8.44 \%)$ and in age group 0-10 years cases were 27(7.12\%). Hence maximum incidences took place in the age range 11-20 years and the frequency of the incidences decreases as the age advances. (Table 2)

In present study 84 cases $(22.16 \%)$ victims were married and in 295 cases $(77.83 \%)$ victims were unmarried showing the more vulnerability of unmarried girls as a prey for sexual offences. (Table 3)

In present study 156 cases $(41.16 \%)$ are from rural area and 223 cases $(58.84 \%)$ are from urban area showing that urban females were at more risk as compared to rural females. (Table 4)

Distribution of cases according to occupation revealed that $236(62.26 \%)$ victims were student, 12 (3.16\%) victims were in government job,17 (4.48\%) victims were in private job, and $60(15.83 \%)$ victims were housewife. in this study $16(4.22 \%)$ victims were labor and 38(10.02) victims were unemployed. Showing the girl students were more exposed to these incidences as compared to other females. (Table 5)

While considering relationship of victim with alleged accused, stranger were $63(16.62 \%)$ while acquaintance were $158(41.68 \%)$, close friends were 89 $(23.48 \%)$, neighbor $29(7.65 \%)$ and near relative 40 $(10.55 \%)$. Hence mere acquaintance is more dangerous as compared to other relations. (Table 6)

In present study most of the incidences took place in assailant's house i.e. in $146(38.52 \%)$ cases. In 127 cases the incidence occurred in victim house $(33.50 \%)$ in 37 cases $(9.76 \%)$ place of incidence was

roadside/isolated place and in 38 cases $(10.02 \%)$ place of incidence was hotel. Hence the presence of accused in lone situation with victim either in victim's house or accused house was proved to be more dangerous for the incidence to happen. (Table 7)

In 75 cases $(19.79 \%)$ there was evidence of external injury. External injury were absent in 304 $(80.21 \%)$ cases hence showing the less resistance during the incidence. (Table 8)

\begin{tabular}{|c|c|c|}
\hline Variables & $\begin{array}{c}\text { Number of } \\
\text { cases }\end{array}$ & Percentage \\
\hline \multicolumn{3}{|l|}{ Year } \\
\hline 2013 & 39 & 10.29 \\
\hline 2014 & 96 & 25.32 \\
\hline 2015 & 100 & 26.38 \\
\hline 2016 & 144 & 37.99 \\
\hline Total & 379 & 100 \\
\hline \multicolumn{3}{|l|}{ Age group } \\
\hline $0-10$ & 27 & 7.12 \\
\hline $11-20$ & 226 & 59.60 \\
\hline $21-30$ & 87 & 22.95 \\
\hline $31-40$ & 32 & 8.44 \\
\hline $41-50$ & 06 & 1.58 \\
\hline $51-60$ & 01 & 0.26 \\
\hline Total & 379 & 100 \\
\hline \multicolumn{3}{|l|}{ Marital status } \\
\hline Married & 84 & 22.16 \\
\hline Unmarried & 295 & 77.83 \\
\hline Total & 379 & 100 \\
\hline \multicolumn{3}{|l|}{ Residence } \\
\hline Rural & 156 & 41.16 \\
\hline Urban & 223 & 58.84 \\
\hline \multicolumn{3}{|l|}{ Occupation } \\
\hline student & 236 & 62.26 \\
\hline government job & 12 & 3.16 \\
\hline private job & 17 & 4.48 \\
\hline housewife & 60 & 15.83 \\
\hline labour & 16 & 4.22 \\
\hline unemployed & 38 & 10.02 \\
\hline \multicolumn{3}{|c|}{ Type of relationship } \\
\hline Acquaintance & 158 & 41.68 \\
\hline Stranger & 63 & 16.62 \\
\hline Close friend & 89 & 23.48 \\
\hline Neighbor & 29 & 7.65 \\
\hline Near relative & 40 & 10.55 \\
\hline \multicolumn{3}{|l|}{ Place of incidence } \\
\hline Victims house & 127 & 33.50 \\
\hline Accused house & 146 & 38.52 \\
\hline Relatives house & 31 & 8.17 \\
\hline $\begin{array}{l}\text { Roadside/Isolated } \\
\text { place }\end{array}$ & 37 & 9.76 \\
\hline Hotel & 38 & 10.02 \\
\hline Total & 379 & \\
\hline \multicolumn{3}{|l|}{ External injury } \\
\hline Present & 75 & 19.79 \\
\hline
\end{tabular}

International Journal of Forensic Medicine and Toxicological Sciences, January-June, 2017:2(1):17-21 


\begin{tabular}{|l|c|c|}
\hline Absent & 304 & 80.21 \\
\hline Total & 379 & 100 \\
\hline
\end{tabular}

\section{Discussion}

According to National Crime Record Bureau of India 24,923 rape cases were reported across India in 2012, while the 5 year average over 2007-2011 was 22,000 rapes a year. Adjusted for population growth over time, the annual rape rate in India has increased from 1.9 to 2.0 per $1,00,000$ people over $2008-2012$ period. ${ }^{(10)}$

Present study included cases from January 2013 to December 2016. In each year there was increase in number of cases. Sweta. L. et. al. ${ }^{(11)}$ and Namita G. et. al. ${ }^{(12)}$ also recorded the year wise increase of rate of cases of sexual offences reported at their concerned institutions. The incidence of cases of sexual assault reporting has now a day's gradually increasing. It is not only due to increase of crime rate but also because of the fact that people are also aware after extensive media coverage of various cases \& coming forward to seek Justice. $^{(11)}$

In this study the age of victim are ranging from 1 to 53 years. Most of the victim was of age group 11 to 20 years consisting of 226 cases $(59.60 \%)$. These results are in agreement with study by Sarkar SC et. al. ${ }^{(13)}$ (68.9\%), Tamuli RP et. al. ${ }^{(14)}(55.76 \%)$, Arif M. et. al. ${ }^{(15)}(68.8 \%)$ Praveen M et. al. ${ }^{(16)}$ (51.6\%) Kumar Pal et. al. ${ }^{(17)}(54.28 \%)$.

In study by Malhotra $\mathrm{N}$ et al, ${ }^{(18)}$ adolescent victim were most common victim (71.9\%). Study by Du Mont $\mathrm{J}$ et. al. ${ }^{(19)}$ recorded majority of victim were between age group 15-20 years. Bhowmic \& Chaliha ${ }^{(20)}$ showed that majority of victim were of age group 18-20 years. Bhardwaj DN et. al. ${ }^{(21)}$ showed that majority of victim $(40.70 \%)$ were $13-20$ years. Islam M. ${ }^{(22)}$ reported $33.5 \%$ victims were of age group 12-15 years. In study done by Sharma DC et. al. ${ }^{(23)}$ majority of alleged rape victim were girls of age group 15-18 years.

From this it is clear that though all ages are vulnerable to sexual assault, the most common age group affected is 11-20 years.

In present study $77.83 \%$ victim were unmarried and similar results were reported by other studies. In study of Sukal B. et al., (24) unmarried victims were 77\% and in study of Kumar Pal et $\mathrm{al}^{(17)}$ the figure was $77.14 \%$. In study by Bhowmik and Chaliha et $\mathrm{al}^{(20)}$ in $66.93 \%$ cases, Praveen et. al. ${ }^{(16)}$ in $63 \%$ cases, Al Azad et. al. ${ }^{(25)}$ in $78.69 \%$ Du-Mont $\mathrm{J}$ et. al, ${ }^{(18)}$ in $68.2 \%$ and Fimate \& Devi, ${ }^{(26)}$ in $57 \%$, Arif M. et. al. ${ }^{(15)}$ in $70.9 \%$ Das et. $\mathrm{al}^{(27)} 76 \%$ and by Tamuli RP et $\mathrm{al}^{(14)}$ in $63 \%$ respectively. According to Sharma DC et. $\mathrm{al}^{(23)}$ it was observed that incidence of rape is more in unmarried girls.

Developed countries no longer document the marital study of victim of sexual violence because it is acceptable in their society for sexual contact to take place even without lawful wedlock. ${ }^{(15)}$
In most of the cases the boy friend gave false assurance to the girls to marry her and due to pettiness that girl gives consent for sexual intercourse but when the boy refuses the marriage with the girl, the girl herself launches the complaint against the boy. ${ }^{(14)}$ Similar type of scenario as revealed from the history was also presented by most of the victims in present study.

In present study 156 cases $(41.16 \%)$ are from rural area and 223 cases $(58.84 \%)$ are from urban area.

In study by Bijoy TH. et. al. ${ }^{(28)}$ recorded that $67.3 \%$ cases were from rural and $32.7 \%$ cases were from urban area. Study by Demisew A. et. al. ${ }^{(29)}$ recorded that $31.3 \%$ cases, were from urban and $68.7 \%$ cases were from rural area.

This difference in proportion of rural and urban area in different studies might be due to difference in socio-cultural backgrounds in different areas. Also it depends on the distribution of population in the study region and referral of cases from the periphery. In our study there is no much difference in cases from rural and urban area. This might be due to less referral of cases from the rural zone as they were examined at Primary Health Centre or Rural Hospital itself.

In present study majority of victim were students comprising of $62.26 \%$ of cases. Study by Kumar et. al. ${ }^{(17)} 48.5 \%$ \& Tailor et. al. ${ }^{(30)}$ showed $23.4 \%$ victims were students. Tamuli RP. et.al. ${ }^{(14)}$ also reported that majority of victims were students 193 cases out of 382 .

Thus these results reveal that students are more vulnerable as compared to other occupations.

In present study $16.62 \%$ assailants were stranger. Study by Sarkar SC et $\mathrm{al}^{(13)}$ recorded $19 \%$ assailant were stranger. Stranger assailants were recorded by Fimate et. al. ${ }^{(26)}$ in $26.6 \%$ cases, by Okonkwo et. al ${ }^{(31)}$ $34.8 \%$ cases, by Riggs et. al ${ }^{(32)} 39 \%$ cases, by Kumar Pal et. al. ${ }^{(17)}$ recorded $20 \%$ cases, by Suri et. al. ${ }^{(33)} 22 \%$ cases. Shinge et. al. ${ }^{(34)}$ showed $9.7 \%$ assailant were stranger in their study. Study by Bhowmik and Chaliha et. al. ${ }^{(20)}$ recorded $16.06 \%$ assailant were stranger. The assailant of this offence ranges from a person who is acquaintance close friend, neighbor, near relative to stranger. The victims can be easily cheated for commission of sexual act by known persons as compared to strangers.

In present study maximum incidence took place at accused house in 146 cases $(38.52 \%)$ followed by victims house in 127 cases (33.50\%)

In Study by Samual O. et al, ${ }^{(35)}$ most incidences occurred at assailant home (50\%). In Study by Kumar Pal et al, ${ }^{(17)}$ also most incidence occurred at alleged accused home (31.40\%).

Study by Sarkar SC et al ${ }^{(13)}$ reported that most of incidences occurred at victim mome (41\%).Study by Grossin $\mathrm{C}$ et $\mathrm{al}^{(36)}$ also reported that most of incidences occurred at victim home (41\%) which are not consistent with our study. 
Study by Arif M. et al ${ }^{(15)}$ showed that most of incidence occurred isolated followed by accused house. This is because many of victims in their study were abducted and then raped.

In present study maximum cases occurred in assailant's house. Whatever may be the place whether house of victim or assailant this could have been because victim knew the assailant and she did not suspect a person she knew could have such malice motive. She can be easily lured to the assailant's house.

In present study external injuries were present in $19.79 \%$ cases. In study by Sarkar SC et al ${ }^{(13)}$ external injuries were present in $6.7 \%$ cases, while in study by Malhotra et. $\mathrm{al}^{(18)}$ external injuries were present in $21.5 \%$ cases. The study by Du-Mont $\mathrm{J}$ et. $\mathrm{al}^{(19)}$ reported external injuries in $64.2 \%$ cases. Evidence of external injuries in victims was shown by Islam \& Islam et.al in $21.5 \%$ cases and by Al-Azad et. $\mathrm{al}^{(25)}$ in $36.09 \%$ cases, by Arif $\mathrm{M}$ et. al. ${ }^{(15)}$ in $10.8 \%$ cases and by Praveen et. al. ${ }^{(16)}$ in $13.9 \%$ cases. In study by Kumar Pal et. al. ${ }^{(17)}$ external injuries were present in $20 \%$ cases.

In some cases the substance bruises are likely to be missed as they appear after 48 hours of assault. Delay in reporting of cases and medical examination might be the other reason for not having evidence of injury. Minor physical injuries healing rapidly may be missed in cases with delayed examination or there may be false allegation. $^{(13)}$

In some cases girls had voluntary sexual inter course with boyfriend and eloped with them. Later on cases were filled by their parents / guardians who did not approve this relationship as the age of girl is less than 18 years. ${ }^{(14)}$

\section{Conclusion}

Comprehensive reporting on all forms of sexual violence is very necessary. Social awareness, sensitization and protection programs should be a high priority. Young girls should receive special attention especially from poor settlements and lower social strata. Most important is that the general attitude of society needs to be changed in favors of the dignity of women and children. Hence, spreading of awareness to encourage early reporting, stringent punishment to the perpetrators and immediate proper care and protection of such innocent victims remain key factors to deal with this heinous crime.

\section{References}

1. Sarkar S C, Lalwani S, Rautji R, Bhardwaj D N and Dogra T D. "Prospective study of victims and offender of sexual offences" The Malaysian journal of Forensic Pathology and Science, June 2008;3(2):10-47.

2. Chattoraj N. "Sex related offences and their preventive and control measures: An Indian perspective" Guest paper in resource material series 72 at $133^{\text {rd }}$ international training course by UNAFEI; 2006; p 82-99.

3. Krug E G, Dahlsberg LL, Mercy J A, Zwi A B, Lozano R, EDS. Chapter 6: sexual violence. In world health report on violence and health. Geneva: world health organization, 2002:147-81.

4. Reddy KSN. "The essentials of forensic medicine and toxicology" 28th edition Hyderabad, India. Om Sai Graphics 2010; p 360.

5. Criminal Law (Amendment) Act, Government of India, 2013. Revised 2013-04-16.

6. Section 376A, Criminal Law (Amendment) Act, 2013. Government of India, 2013. Revised 2014-04-16.

7. El-Elemi AH, Moustafa SM, Hagras AM. Reported cases of female sexual assault over 5 years period in Suez Canal area, Egypt: Demographics. Egyptian Journal of Forensic Sciences 2011;1(3-4):118-12.

8. Information excerpted from the United Nations SecretaryGeneral's In-depth study on violence against Women, 2006, and from websites for the United Nations Fund for Women (UNIFEM) and United Nations Population Fund (UNFPA), unless otherwise specified. Published by the United Nations Department of Public Information DPI/2498 -- February 2008.

9. Beebe, D.K. Emergency management of the adult female rape victim. American family physician, 43:2041$2043 ; 1991$.

10. National Crimes Record Bureau, Crime in India 2012 Statistics Government of India (May 2013).

11. Sweta L, Alpana S, Neelam B Vaid, Sanjeeta B, Sexual Assault Survivors Reporting to a Tertiary Care Hospital in Delhi: A Retrospective Analysis .Journal of Clinical and Diagnostic Research. 2014 Sep, Vol-8(9): OC09OC12.

12. Namita G, Amita Suneja, NB Vaid, Upasana Pandit. Female Sexual Assault: A Study from East Delhi. Indian Internet Journal of Forensic Medicine \& Toxicology 2008;6(4).

13. Sarkar SC, Lalwani S, Rautji R, Bhardwaj DN, Dogra TD.A study on victims of sexual offences in South Delhi. J FAM welf 2005;51(1):[7] 60-6.

14. Tamuli RP Paul B Mahanta P. A statistical analysis of alleged victims of sexual assault - A retrospective study. J Punjab Acad Forensic Med Toxicol 2013;13(1):7-13.

15. Arif M, Ahmed M, hanif F. Natural sexual offences; medicolegal assessment in Punjab. Professional Med J 2014;21(5):980-986.

16. Parveen M, Nadeem S, Aslam M, Sohail K. Female victims of sexual violence; reported cases of in Faisalabad city in 2008. Professional Med J Dec 2010;17(4):735-40.

17. Kumar-Pal, Sharma, Kumar Sehgal, Singh-Rana A Study of Sexual Assaults in Northern Range of Himachal Pradesh International Journal of Medical Toxicology and Forensic Medicine. 2015;5(2): 64-72.

18. Malhotra N, Sood M. Sexual assaut, a neglected public health problem in developed world. Int J Obs Gyn. 2000;71:257-8.

19. Du Mont J and Parnis D. Sexual assault and legal resolution: Querying the medical collection of Forensic evidence. Med Sci Law. 2000; 19(4):779-792.

20. Bhowmik K, Chaliha R. A Descriptive One Year Study on the Alleged Male and Female Victims and Accused of Sex Crimes. J Indian Acad Forensic Med. 2011;33(3):214-2.

21. Bhardwaj DN, Sharma RK, Sagar MS, Murty OP. Study of sexual offences in South Delhi. J Forensic Med Toxicol. 1995; XII(3\&4):33-4.

22. Islam M. Retrospective study of alleged rape victims attended at Forensic Medicine department of Dhaka Medical College, Bangladesh. Legal Med (Tokyo).2003; suppl 1:351-3. 
23. Sharma DC, Aggarwal KK and Bhullar DS. Analysis of vaginal swab examination vis-à-vis magnitude of rape in Punjab. J Indian Acad Forensic Med. 2008;30(4):186-92.

24. Sukul B, Chattopadhyay S and Bose TK. A Study of the Victims of Natural Sexual Offence in the Bankura District in West Bengal. J Indian Acad Forensic Med. 2009;31(1):25-9.

25. Al-Azad MAS, Rahman Z, Ahmad M. Sociodemographic characteristics of alleged sexual assault (rape) cases in Dhaka city. JAFMC Bangladesh. 2011;7(2):21-4.

26. Fimate L, Devi M, An analytical study of rape in Manipur. International Journal of Medical Toxicology and Legal Medicine. 1998;(1):1-2.

27. Das I, Chakraborty A, Batabyal S, Sukul B, Dhar G. A study on the Socio-demographic profile of the victims of sex offences attending the Department of Forensic Medicine of a Tertiary Care Institute of Kolkata, West Bengal. IOSR-JDMS 2013;(11)4:43-47.

28. Bijoy TH, Pradipkumar KH, Lepcha OT. A study of child rape in Manipur. J Indian Acad Forensic Med 2006;28:135-7.

29. Demisew A, Desta H. Sexual assault: pattern and related complications among cases managed in JIMMA University specialized hospital. Ethiop J Health Sci. Vol. 24, No. 1 January 2014,3-12.

30. Tailor C, Govekar G, Patel G, Silajiya D. The profile of age in cases of victims of sexual offence. J Indian Acad Forensic Med. 2010;32(4):303-7.

31. Okonkwo JEN, IIbeh C. 2003. Female Sexual Assault in Nigeria. International Journal of Gynaecology and Obstetrics; 83(3):325-26.

32. Riggs N, Houry D, Long G, Markovchick V, Feldhaus KM. Analysis of 1076 cases of sexual assault. Ann Emerg Med.2000;35:358-62.

33. Suri S, Sanjeeda. An analytical study of rape in Delhi. International Journal of Education and Psychosocial Research. 2013;2(3):60-8.

34. Shinge SS, Shrigiriwar MB. Medico-legal examination of accused of alleged rape cases-a prospective study. J Indian Acad Forensic Med. 2013;35(4):332-5.

35. Samuel O, Julius W, Paul K, Robert B. Clinical presentation and management of alleged sexually assaulted females at Mulago hospital, Kampala, Uganda. African Health Sciences 2005;5(1):50-54.

36. Grossin C, Sibille I, Grandmaison GIDI, Banasr A, Brion F, Durigon M. Analysis of 418 Cases of Sexual Assault, Forensic Science Int. 2003;131:125-30. 